\title{
Kolorektal polip sonuçlarımız; endoskopik ve histolojkk verilerimizin güncel çalışmalarla karşılaştırılması
}

\author{
Results obtained from colorectal polyps; comparison of our endoscopic and histological data with \\ current studies
}

(D) Atilla BULUR ${ }^{1}$, (D) Pembegül YUMUŞTUTAN²

Istanbul Yeni Yüzyll Üniverstitesi Tip Fakültesi, Özel Gaziosmanpașa Hastanesi, ${ }^{1}$ Gastroenteroloji Bölümü, Istanbul

Üsküdar Devlet Hastanesi, ${ }^{2}{ }_{1 c ̧}$ Hastalıları Bölümü, Istanbul

Giriş ve Amaç: Kolorektal kanserler dünyada ve ülkemizde en sık görülen kanserlerdendir ve çok büyük oranda kolorektal poliplerinden gelişirler. Biz bu denli önem arz eden poliplerin ünitemizdeki prevalansinı, endoskopik ve histolojik özelliklerini ortaya koymayı amaçladık. Gereç ve Yöntem: 20162019 yılları arasında gastroenteroloji ünitesi endoskopi laboratuvarımızda erişkin hastalara, herhangi bir nedenle yapılmıs olan kolonoskopik incelemeler etik kurul onayı alınarak retrospektif olarak tarandı. Kolonoskopik islemlerde rastlanıp snare ya da forseps yardımı ile polipektomi uygulanan ya da biyopsi alınan polipler ayrilarak, bu poliplerin endoskopik (lokalizasyonu, boyutu, sayısı) ve histolojik (histopatolojik tanı, displazi, kanser) özellikleri incelendi. Elde edilen veriler IBM SPSS 22.0 istatistik programinda analiz edildi. Bulgular: Çalışmamızda 2068 hastaya ait işlemlerin 362'sinde (\%17.50) polip ya da poliplere rastlanılmıştı. Polip saptanan hastaların yaş ortalaması $59.86 \pm 11$ (19-92) yıl, erkeklerin yas ortalaması 60.36 yıl, kadınların yas ortalaması 59.16 yıldı. Vakaların 236's1 (\%65) erkek, 126's1 (\%35) kadındı. Çalışmamızda poliplerin boyutlarına göre dağılımı; 298 (\%66.81) diminutif polip, 117 (\%26.23) küçük polip, 31 (\%6.95) büyük polip olarak saptandı. En fazla sayıda polip görülen lokalizasyon sigmoid kolon ( $n=158$, \%35.42), en az sayıda polip görülen lokalizasyon ise çekumdu ( $n=11$, \%2.46). Çalışmamızda histolojik olarak polipler neoplastik ( $n=270, \% 60.54)$ ve non neoplastik ( $n=179, \% 39.46)$ olarak iki ana grupta incelendi. En sik görülen histolojik tanı neoplastik polipler grubundan adenomlardı ( $n=254$, $\% 56.95)$, adenomlar içinde en sik tübüler adenomlar $(n=222, \% 87.40)$ görülmekteydi. Adenomlardan sonra en sık görülen tanı ise hiperplastik poliplerdi (n=131, \%29.4). Poliplerin displazi/kanser özellikleri gözden geçirildiğinde 246 (\%55.16) polipte düşük dereceli displazi, 6 (\%1.35) polipte yüksek dereceli displazi, 1 (\%0.22) polipte intramukozal adenokarsinom saptandı. Proksimal kolona doğru gidildikçe poliplerin neoplastik özellikler artmaktaydı. Sonuç: Calıșmamız yakın zamanda yapılmıș güncel kolon polip prevalans çalışmaları ile karşılaştırılarak yapıldı. Çalışmamızda ülkemiz oranlarına yakın kolorektal polip prevalansının yanısıra benzer çalışmalara göre displastik özellikler içeren polip sıklığımızın fazla oluşu dikkat çekiciydi. Bu durum kolonoskopik tarama ve takip programlarına verilmesi gereken önemi ve özeni bir kez daha göstermekteydi.

Anahtar kelimeler: Kolorektal polip, kolorektal kanser, prevalans, boyut, lokalizasyon, histoloji

\section{GİRISs}

Kolorektal polipler, mukoza veya submukoza epitelinden köken alan, barsak lümeni içine çıııntı yapıp kitle oluşturan lezyonlardır $(1,2)$. Polipler kolorektal kanserlerin (KRK) öncü lezyonları olmalarından dolayı önem arz etmektedir.
Bacground and Aims: Colorectal cancer is one among the most frequent cancers globally, and it usually results from colorectal polyps. We herein aimed to reveal the endoscopic and histological features of such polyps, and the prevalence of such polyps in our unit. Materials and Methods: Colonoscopic procedures carried out for any reason in adult patients in our endoscopy laboratory of the gastroenterology unit between 2016 and 2019 were retrospectively screened with an approval of the ethics committee. Polyps that were encountered in colonoscopic procedures and underwent polypectomy with the help of snare or forceps or biopsied were seperated and endoscopic (localization, size, and count) and histological (histopathological diagnosis, dysplasia, and cancer) features of the identified polyps were studied. The resulting data were analyzed in IBM SPSS 22.0. Results: In our study, one or more polyps were found in 362 (17.50\%) of the colonoscopy procedures of 2068 patients. Mean age of patients with a polyp was $59.86 \pm 11$ (19-92) years; mean age of men was 60.36 years and mean age of women was 59.16 years. Of all cases, 236 (65\%) were men, and 126 (35\%) were women. The distribution of polyps by size in our study was as follows: 298 (66.81\%) diminutive polyps, 117 (26.23\%) small polyps, and 31 (6.95\%) large polyps. Polyps were found to be localized mostly in the sigmoid colon ( $n=158,35.42 \%)$, and least frequently in the cecum. In our study, polyps were histologically examined under two main categories as neoplastic ones $(n=270,60.54 \%)$ and non-neoplastic ones $(n=179,39.46 \%)$. The most common histological diagnosis was adenomas from the group of neoplastic polyps $(n=254,56.95 \%)$, and the most frequent type of adenoma was tubular adenoma $(n=222,87.40 \%)$. The second most common diagnosis after adenomas was hyperplastic polyps ( $n=131,29.4 \%)$. A low-grade dysplasia in 246 (55.16\%) polyps, a high-grade dysplasia in 6 (1.35\%) polyps, and an intramucosal adenocarcinoma in $1(0.22 \%)$ polyp were identified when dysplasia/cancer features of polyps were reviewed. An increasing number of neoplastic features was apparent toward the proximal colon. Conclusion: This study was carried out in comparison with the recent studies on the prevalence of colon polyps. In our study, the presence of an increased frequency of polyps having dysplastic features, along with colorectal polyps, which is close to the respective prevalence rate in our country, compared to that in similar studies, was also noteworthy. This reaffirmed the importance of colonoscopy screening and follow-up programs.

Key words: Colorectal polyp, colorectal cancer, prevalence, size, localization, histology

KRK dünyada ve Türkiye'de en yaygin görülen kanserlerdendir ve kansere bağlı mortalite ve morbiditenin önde gelen nedenlerindendir $(3,4)$. Histolojik özelliklerine göre polipler genel anlamda neoplastik (benign: adenomalar, malign: kar- 
sinomalar...) ve non neoplastik (hiperplastik, inflamatuvar, hamartomatöz, peutz-jeghers polibi, ...) polipler olarak iki grupta incelenir. Poliplerin klinik açıdan en önemli grubunu KRK'e dönüşüm riski olan ve tüm kolorektal poliplerinin 2/3'ünü oluşturan ve neoplastik polipler grubunun ana öğesi olan adenomlar (adenomatöz polipler) oluşturur. Adenomlar histolojik olarak tübüler, tübülovillöz ve villöz adenomlar olarak üç tipe ayrılır. Adenomlar içinde en sık görülen histolojik tip tübüler adenomlardır, tübüler adenomlar genellikle diminutiftir ve low grade displazi (LGD) özelliği taşırlar. Polipler boyutlarına göre diminutif ( $\leq 5 \mathrm{~mm})$, küçük (6-9 mm) ve büyük ( $\geq 10 \mathrm{~mm}$ ) polipler olarak üç gruba ayrılır. Kolonoskopide saptanan poliplerin büyük kısmını boyutu $1 \mathrm{~cm}$ altında olan diminutif ve küçük polipler oluşturmaktadır. Polip çapının artması ile villöz özellikler (tübülovillöz ve villöz adenom), displazi [özellikle high grade displazi (HGD)] sıklığı artmaktadır, bu durum KRK dönüşüm riskini arttırmaktadır. Non neoplastik polip grubunda en sık hiperplastik polipler görülür, bu polipler genellikle sesil ve boyutları 1-3 mm civarinda diminutif poliplerdir $(5,6)$. Hiperplastik polipler bugün en çok tartışılan polip grubudur, geleneksel sinıflandırmada neoplastik değildirler, ancak çalışmalarda bu poliplerin serrated polipler olarak bilinen daha büyük bir polip grubunun bir parçası olduğu belirtilmektedir. Serrated poliplerin değişken malign potansiyele sahip heterojen bir polip grubu olduğu düşünülmektedir $(7,8)$. Bu bilgiler ışığında neoplastik polip grubunun ve tüm kolorektal polip tiplerinin en sik görülen histolojik lezyonu olan adenomatöz poliplerin tanınması ve eksizyonu KRK ilişkili mortaliteyi azaltmakta ve sağ kalımı arttırmaktadır (9-11). Coğrafi farklılıklar olsa da ileri yaşlarda ve erkek cinsiyette adenomatöz poliplerin sılklı̆ı, büyüklüğü ve displazi gelişme oranı da artmaktadır, ayrıca abdominal obezitenin de adenomatöz polip ve displazi gelişimi için risk faktörleri olduğunu gösteren çalışmalar mevcuttur (12-15). Literatürde, kolorektal poliplerin sıklığı erkeklerde \%53-59, kadınlarda \%40-46 civarında bildirilmektedir $(16,17)$. Lokalizasyon açısından değerlendirildiğinde polipler distal kolon ve rektumda daha sık görülürken,1980'den sonra yapılan çalışmalarda kolon kanserlerinin sol kolondan sağa doğru değişim göstermekte olduğu görülmektedir $(18,19)$. Kolonoskopik incelemeler; gastrointestinal kanama, açıklanamayan demir eksikliği anemisi, kronik ishal, inflamatuvar barsak hastalığı şüphesi, kolorektal kanser taraması gibi endikasyonlar nedeniyle yapilabilir. Kolon polipleri; rektal kanama, anemi, obstrüksüyon ve ishal gibi klinik semptom ve bulgulara neden olabilir. Amerikan Kanser Derneği'nin (ACS) 2018 yllında revize edilen KRK tarama kllavuzunda (American Cancer Society Guideline for Colorectal Cancer Screening); ortalama riske sahip bireylerde 45 yaşından itibaren kolonoskopik taramaya başlanması önerilmektedir (20). Amerikan Gastroenteroloji Derneği'nin (ACG) 2012 yılında yayınlanan en son kilavuzunda (Guidelines for Colonoscopy Surveillan- ce After Screening and Polypectomy ); hiperplastik histolojisi olan distal kolondaki (rektum ve sigmoid kolon) 10 mm'den küçük polip ya da polipleri bulunan hastaların polibi olmayan sağlıklı insanlar gibi 10 yıl ara ile taranması önerilirken, $10 \mathrm{~mm}$ altında ve 1-2 adet tübüler adenomu olan hastaların 5-10 yıl, 3-10 adet tübüler adenomu olanlarda ve boyut ve sayıdan bağımsız villöz histolojide polibi olan hastaların 3 yıl ara ile taranması önerilmektedir (21).

\section{GEREC ve YÖNTEM}

Ekim 2016 ile Haziran 2019 tarihleri arasında Üsküdar Devlet Hastanesi, Gastroenteroloji Bölümü Endoskopi Ünitesi'nde, erişkin hastalara, herhangi bir nedenle yapılmış ve otomasyon sistemi üzerine kaydedilmiş olan, kolonoskopik incelemelerinde polip ya da polipler saptanan 2068 hastanın işlemlerine ait veriler etik kurul onayı (Zeynep Kamil Kadın ve Çocuk Hastalıkları EAH Klinik Araştırmalar Etik Kurulu, 22.05.2019, Karar No:53) alınarak retrospektif olarak tarandi. Kolonoskopi sirasinda tespit edilen, snare ya da forseps yardımı ile polipektomi ya da biyopsi uygulanan poliplerin endoskopik ve histopatolojik özellikleri detaylı olarak incelendi. Bilinen ya da inceleme sırasında karşılaşılan inflamatuvar barsak hastalığı, iskemik kolit, kolon kanseri gibi kolonik hastalığı olan hastalar çalışmaya alınmadı.

Ayrıca az sayıdaki hastada gördügümüz aynı hastaya ait mükerrer işlemler çalışmaya alınmadı. Işleme alınan hastalar, işlemden önceki günün sabahından itibaren sıvı ve şeffaf diyet ile beslenmişler, yine işlemden bir gün önce polietilen glikol ya da sennosid solüsyon laksatifleri ile kolonoskopi hazırlığı yapmışlardı. Işlem sırasında anestezi hekimi tarafından sedoanaljezi uygulamıştı. İşlemler "Fujinon EC-450LS5, Japan" seri numaralı ve markalı kolonoskopi cihazı ile yapılmıştı. Kolonoskopi sırasında görülen polipler forseps ya da snare yardımı ile eksize edildi ve patoloji laboratuvarına \%10 formol solüsyonu içinde iletildi. Poliplerin histopatolojik değerlendirmesi kendi merkezimizde çalışmakta olan üç patoloji hekimi tarafından yapıldı. Elde edilen veriler bilgisayar ortamında IBM SPSS Statistics 22.0 programında analiz edildi.

\section{BULGULAR}

Ünitemizde iki buçuk yılı aşkın süre içinde 2068 adet hastanın kolonoskopik incelemesinin 362'sinde polip ya da poliplere rastlanılmıştı. Bu 362 işlemde toplam 446 adet polip saptanmıştı, yani kolonoskopik işlemlerin \%17.50'sinde, bir başka deyişle yaklaşık altı işlemden birinde polip ya da poliplere rastlanılmıştı. Incelememizde polip görülen işlemlerde işlem başına 1.23 adet polip çıkarılmıştı. Polip saptanan hastaların yaş ortalaması 59.86 11 (19-92) yıl, erkeklerin yaş ortalaması 60.36 yıl, kadınların yaş ortalaması 59.16 yıldı. Vakaların 236'sı (\%65) erkek, 126'sı (\%35) kadındı. Çalışmamızda poliplerin boyutlarına göre dağılımı; 298 (\%66.81) di- 
minutif polip, 117 (\%26.23) küçük polip, 31 (\%6.95) büyük polip olarak saptandı. Poliplerin distalden proksimale doğru lokalizasyonlarına göre dağılımı ise şöyleydi; rektumda 51, (\%11.43), sigmoid kolonda 158 (\%35.43), inen kolonda 73 (\%16.37), transvers kolonda 116 (\%26.01), çıan kolonda 39 (\%8.74) ve çekumda 9 (\%2.02) polip yerleștiği görüldü. En sık görülen polip lokasyonu sigmoid kolon, en az görülen lokasyon ise çekumdu (Tablo 1, Grafik 1). Poliplerin histolojik özelliklerine değinecek olursak; en sık görülen histolojik tanı 254 (\%56.95) vaka ile adenomlardı, adenomlar içinde 222 (\%87.40) vakada tübüler adenom, 29 (\%11.41) vakada tübülovillöz adenom, 3 (\%0.67) vakada villöz adenom saptanmıştı. Adenomlardan sonra en sık görülen tanılar ise; 131 (\%29.4) vaka ile hiperplastik polipler, 19 (\%4.3) vaka ile non spesifik/ödematöz mukoza, $18(\% 4.0)$ vaka ile inflamatuvar polipler, 14 (\%3.1) vaka ile serrated polipler, 4 (\%0.89) vaka ile lipomatöz lezyonlar, $2(\% 0.44)$ vaka ile eozinofilik mukoza/eozinofilik kolit, l'er (\%0.22) vaka ile hamartomatöz polip, melanozis koli, nöroendokrin tümör ve intramukozal adeno karsinom (intramukozal adeno $\mathrm{Ca}$ ) olarak belirlendi (Tablo 1). Çalışmamızda en sık görülen histolojik tanı olan tübüler adenomlar en fazla transvers kolonda görülmüşken, neredeyse diğer bütün histolojik tanılar en sik sigmoid kolonda görülmüştür. Çalışmamızda neoplastik polip (adenomlar, nöroendokrin tümör, intramukozal adeno Ca) sayısı 270 (\%60.54), non neoplastik polip sayımı 176 (\%39.46) olarak saptandı. Neoplastik poliplerin lokalizasyona göre dağılımı şöyleydi; rektumda 17 adet, sigmoid kolonda 84 adet, inen kolonda 54 adet, transvers kolonda 79 adet, çıkan kolonda 31 adet, çekumda 5 adet saptandı. Sağ kolona doğru gidildikçe neoplastik polip görülme sıklığının arttığı dikkat çekiciydi (Tablo 2, Grafik 1). Poliplerin displazi özellikleri gözden geçirildiğinde 246 (\%55.16) polipte LGD, 6 (\%1.35) polipte HGD saptanmışken, kanser olarak 1 nöroendokrin tümör ve 1 intramukozal adeno Ca (bazal membranı aşmamış, karsinoma insitu olarak ta tanımlananan adeno kanserin ilk evresi) olmak üzere 2 polipte kanser (\%0.44) saptanmıştır.

Tablo 1. Poliplerin lokalizasyon ve histolojik özellikleri

\begin{tabular}{|c|c|c|c|c|c|c|c|}
\hline Histolojik Tanı & Rektum & $\begin{array}{l}\text { Sigmoid } \\
\text { Kolon }\end{array}$ & $\begin{array}{l}\text { İnen } \\
\text { Kolon }\end{array}$ & $\begin{array}{l}\text { Transvers } \\
\text { Kolon }\end{array}$ & $\begin{array}{l}\text { Çlkan } \\
\text { Kolon }\end{array}$ & Çekum & $\begin{array}{l}\text { Toplam } \\
\text { N (\%) }\end{array}$ \\
\hline \multicolumn{8}{|l|}{ Adenomlar } \\
\hline Tübüler adenomlar & 14 & 64 & 43 & 69 & 28 & 4 & $\begin{array}{c}222 \\
(\% 49.78)\end{array}$ \\
\hline Tübülovillöz adenomlar & 0 & 11 & 7 & 8 & 2 & 1 & $\begin{array}{c}29 \\
(\% 6.50)\end{array}$ \\
\hline Villöz adenomlar & 0 & 2 & 1 & 0 & 0 & 0 & $\begin{array}{c}3 \\
(0.67)\end{array}$ \\
\hline Hiperplastik polip & 22 & 62 & 14 & 24 & 6 & 3 & $\begin{array}{c}131 \\
(\% 29.37)\end{array}$ \\
\hline Non spesifik/ödematöz mukoza & 0 & 5 & 4 & 9 & 1 & 0 & $\begin{array}{c}19 \\
(\% 4.26)\end{array}$ \\
\hline Inflamatuvar polip & 5 & 5 & 0 & 5 & 0 & 3 & $\begin{array}{c}18 \\
(\% 4.03)\end{array}$ \\
\hline Serrated polip/adenom & 2 & 6 & 3 & 2 & 1 & 0 & $\begin{array}{c}14 \\
(\% 3.14)\end{array}$ \\
\hline Lipomatoz lezyon & 1 & 0 & 1 & 2 & 0 & 0 & $\begin{array}{c}4 \\
(\% 0.90)\end{array}$ \\
\hline Eozinofilik mukoza/kolit & 1 & 0 & 0 & 0 & 1 & 0 & $\begin{array}{c}2 \\
(\% 0.45)\end{array}$ \\
\hline Nöroendokrin tümör & 1 & 0 & 0 & 0 & 0 & 0 & $\begin{array}{c}1 \\
(\% 0.22)\end{array}$ \\
\hline Melanozis koli & 0 & 1 & 0 & 0 & 0 & 0 & $\begin{array}{c}1 \\
(\% 0.22)\end{array}$ \\
\hline Hamartomatöz polip & 0 & 1 & 0 & 0 & 0 & 0 & $\begin{array}{c}1 \\
(\% 0.22)\end{array}$ \\
\hline Intra mukozal adeno $\mathrm{Ca}$ & 0 & 1 & 0 & 0 & 0 & 0 & $\begin{array}{c}1 \\
(\% 0.2)\end{array}$ \\
\hline Toplam & $\begin{array}{c}46 \\
(\% 10.31)\end{array}$ & $\begin{array}{c}158 \\
(\% 35.42)\end{array}$ & $\begin{array}{c}73 \\
(\% 16.36)\end{array}$ & $\begin{array}{c}119 \\
(\% 26.68)\end{array}$ & $\begin{array}{c}39 \\
(\% 8.74)\end{array}$ & $\begin{array}{c}11 \\
(\% 2.46)\end{array}$ & $\begin{array}{c}446 \\
(\% 100)\end{array}$ \\
\hline
\end{tabular}




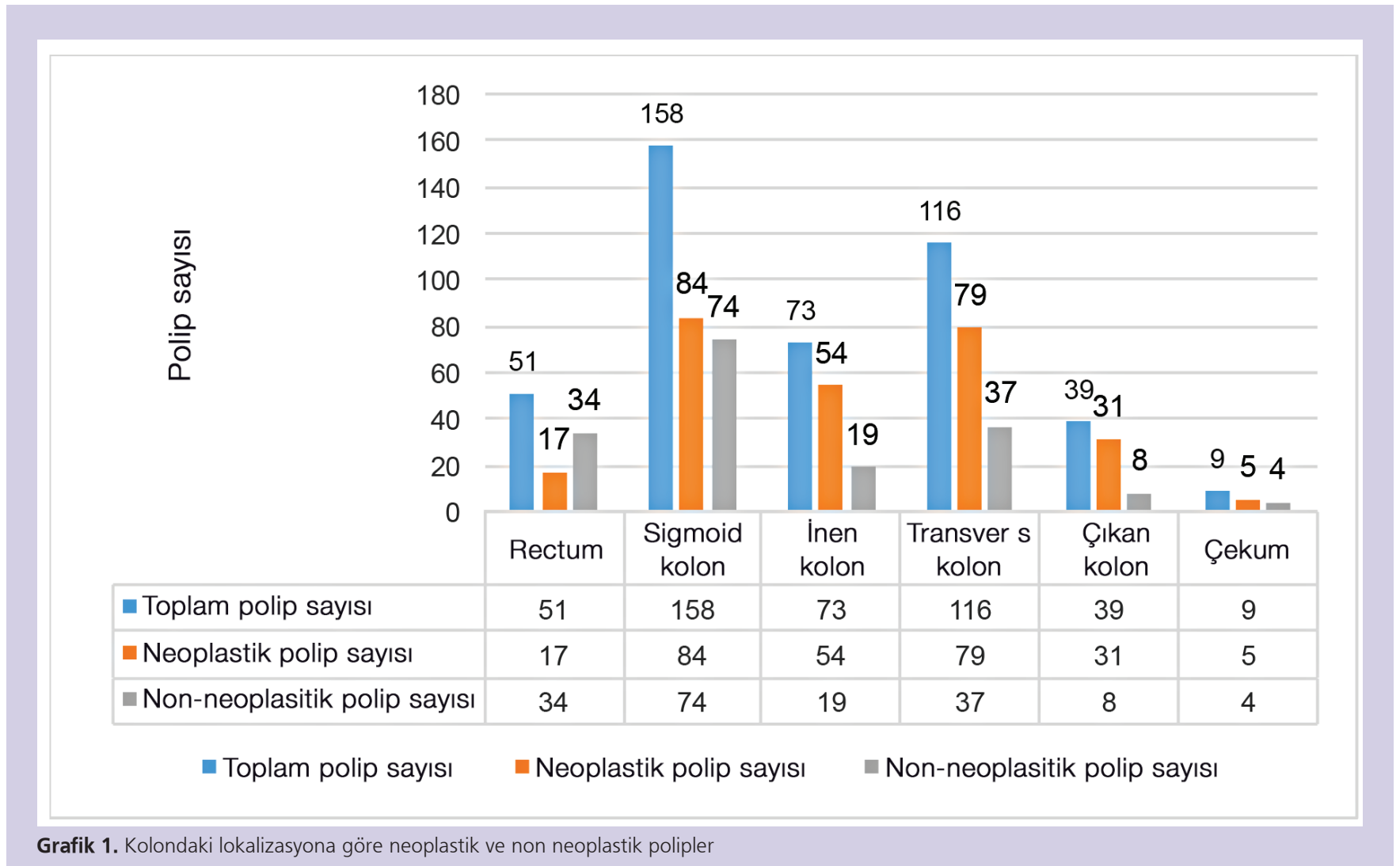

Tablo 2. Ülkemizde yakın zamanda yapılan benzer çalışmalarla karşılaştırma

\begin{tabular}{|c|c|c|c|c|c|}
\hline & $\begin{array}{c}\text { Eminler ve ark. } \\
(2011)\end{array}$ & $\begin{array}{l}\text { Solakoğlu ve ark. } \\
\qquad(2014)\end{array}$ & $\begin{array}{c}\text { Korkmaz ve ark. } \\
(2016)\end{array}$ & $\begin{array}{c}\text { Şahintürk ve ark. } \\
\text { (2018) }\end{array}$ & $\begin{array}{c}\text { Bizim Çalışmamız } \\
(2020)\end{array}$ \\
\hline Polip prevalansı & $\% 22.06$ & $\% 11.1$ & $\% 14.4$ & $\% 34.9$ & $\% 17.50$ \\
\hline Yaş & 59.82 & 59.00 & 57.40 & 55.41 & 59.86 \\
\hline Erkek/ kadın & 1.42 & 2.19 & 1.64 & 0.87 & 1.86 \\
\hline Lokalizasyon & $\begin{array}{c}\text { Rektosigmoid } \\
(\% 47)\end{array}$ & $\begin{array}{l}\text { Rektum } \\
\text { (\%33) }\end{array}$ & $\begin{array}{l}\text { Rektum } \\
(\% 37.7)\end{array}$ & $\begin{array}{l}\text { Rektum } \\
\text { (\%36.9) }\end{array}$ & $\begin{array}{l}\text { Sigmoid Kolon } \\
(\% 35.4)\end{array}$ \\
\hline Neoplastik polip & $\% 75.7$ & $\% 81.73$ & $\% 74.4$ & $\% 76.25$ & $\% 60.5$ \\
\hline
\end{tabular}

\section{TARTIŞMA}

KRK'ler dünyada ve ülkemizde en sık görülen tümörlerdendir. 2020 yılı Ocak ayında revize edilen Amerikan Kanser Derneğinin (ACS) istatistiklerinde KRK'ler ABD'de kadın ve erkeklerde kansere bağlı ölümlerin üçüncü nedeniyken, kadın ve erkeklerin tamamı ele alındığında kansere bağlı ölüm nedenleri arasında en sik ikinci neden KRK'ler olarak bildirilmiștir (22). KRK'lerin öncü lezyonları olan başta adenomatöz polipler olmak üzere polipler bu nedenle önem arz etmektedirler. National Polyp Study Workgroup tarafindan kolonoskopik polipektominin KRK insidansını \%76-90 oranında azalttığ1 bildirilmiştir (23). Ülkemizde kolon polip prevalansını belirleyecek geniş çapta bir çalışma henüz mevcut değildir. Mev- cut çalışmalarda ortalama \%20-25 civarında prevalans bildirilmiştir (24). Ülkemizde yakın zamanda yapılan çalışmalara göz atacak olursak (Tablo 2), kronolojik sirayla 2011, 2014, 2016 ve 2018 yıllarında yayınlanmış; Eminler ve ark, Solakoğlu ve ark., Korkmaz ve ark. ve Şahintürk ve ark.'nın yaptığı çalışmalarda sırasıyla; \%22.06, \% 11.1, \% 14.4, \%34.9'luk polip prevalansları saptanmıştır $(2,17,25,26)$. Şahintürk ve ark. çalışmasında elde edilen \%34.9'luk yüksek polip prevalansı ülkemiz ortalamalarının üzerinde Avrupa ve ABD'de yapılan birçok prevalans çalışma sonucuna benzerlik göstermektedir. Bizim çalışmamızda \%17.50 oranında polip saptanmış olup 2100 hastayı içeren, 360 polibin tespit edildiği, 
3 yllık veriyi analiz eden Korkmaz ve ark. çalışmasına vaka sayısı, verilerin elde edildiği zaman aralı̆̆ı ve polip prevalansı olarak çok benzemektedir (2). Polip saptanan hastaların yaş ortalaması açısından literatür incelendiğinde erkeklerde 5359 yaş, kadınlarda 40-46 yaş ve genel yas ortalaması $43-61$ yaş arasında değişmektedir (27). Ülkemizde yapılan yukarıda adı geçen çalışmalarda sırasıyla; ortalama yaş 59.82, 59.00, $57.40,55.41$ yaş ve hastaların $\% 59.3^{\prime}$ ü, \%69.3'ü, \%62.1'i ve \%46.6'sı erkek olarak saptanmışken $(2,17,25-27)$, bizim çalışmamızda ortalama yaş 59.86 11 (19-92) yll olarak ülkemiz çalışmalarına çok benzerdir. Vakalarımızın \%65’i erkek, \%35’i kadın, erkeklerin yaş ortalaması 60.36 yıl, kadınların yaş ortalaması 59.16 yl olarak ve literatürden biraz daha yüksek olarak saptanmıştır. Literatür incelendiğinde ileri yaş ve erkek cinsiyette daha fazla polip prevalansının arttı̆̆ görülmektedir. Adenomatöz polipler özellikle 50 yaşın üzerinde artmakta olup, otopsi serilerinde 70 yaş üzerinde kolorektal adenom prevalansının \%50'ye yakın olduğu bildirilmiştir (28). Çalışmamızda neredeyse altı işlemden birinde polip ya da poliplerin görüldüğü anlaşılmakta olup, literatürdeki diğer çalışmalar da göz önüne alındığında bu durum özellikle ileri yaşlarda ve özellikle de erkeklerde her 3-6 bireyden birinde her an çıkarılmayı bekleyen polip ya da poliplerin varlığını düşündürmektedir. Bu yüksek prevalans kolonoskopik tarama programlarına verilmesi gereken önemi bir kez daha ön plana çıkarmaktadır.

Kolorektal polipler lokalizasyonları açısından değerlendirildiğinde distal kolon ve rektumda daha sık görülürler $(18,19,29)$. Ülkemizde yukarıda adı geçen çalışmalarda sırasıyla \%47 (lokalizasyon olarak rektosigmoid olarak belirtilmiş), \%36.9, \%37.7, \%33 ile en sik lokalizasyon rektum, en az lokalizasyon çekum olarak bildirilmişken $(2,17,25,26)$, bizim çalışmamızda ise en sık polip lokalizasyonu \%35.42 oranı ile sigmoid kolon olarak saptanmıştır. Rektumda polip görülme oranımı \%10.31 gibi literatüre göre daha düşük orandadır, çekum bizim çalışmamızda da poliplerin en az rastlandığı lokalizasyondur (Tablo 1-2, Grafik 1). Incelememizde sol kolon polip sıklığımız daha fazla olup tüm poliplerin \%62,09'u rektumu da içeren sol kolon yerleşimlidir. Bu bulgumuz literatürdeki yeni dönem çalışmalar ile uyumlu iken, eski çalışmalarla uyumsuzdur (30,31). Bir polipten malignite gelişmesi açısından polip boyutu (adenom $\geq 10 \mathrm{~mm}$ ), artan polip sayısı ve ileri histolojik özellikler ( $>25 \%$ villöz histoloji, HGD ya da kanser varlığı) önemli kriterlerdir (32). Diminutif ve küçük poliplerde ileri histolojik özelliklere büyük poliplere nazaran daha az siklıkla rastlanır $(24,32,33)$. Polip boyutlarına göz atacak olursak, çalışmamızda literatüre benzer şekilde diminutif, küçük ve büyük polip oranlarımız sırasıyla \%66.81, \%26.23, \%6.95 olarak saptanmışken, Korkmaz ve ark., Butterly ve ark., Eminler ve ark., Suna ve ark. yaptığı çalışmalarda sırasıyla; \%75, \%58.7, \%69.5 ve \%87.5 oranında $1 \mathrm{~cm}$ altında polip sıklıkları rapor edilmiş- tir $(2,17,34,35)$. Çalışmamızda literatürden daha fazla sayıda $1 \mathrm{~cm}$ altı polip sıklığı saptanmıştır. Polip histolojilerine göz atacak olursak; literatüre göre kolorektal poliplerin çoğu tüm poliplerin 2/3 kadarını oluşturan neoplastik polip grubundan olan adenomatöz poliplerdir, adenomatöz poliplerin yaklaşık \%80-86'sını tübüler adenomlar, \%3-16'sını villöz adenomlar ve \%8-16'sını tübülovillöz adenomlar oluşturmaktadır $(5,23,35)$. Bizim çalışmamızda neoplastik polip oranımız \%60.54, non neoplastik polip oranımız \%39.46 olarak saptanmıştır. Sağ kolona yani proksimale doğru gidildikçe neoplastik polip görülme oranımızın arttı̆̆ı görülmektedir (Grafik 1). Çalışmamızda neoplastik polipleri (\%60.5) oluşturan lezyonlar; tübüler adenomlar ( $\mathrm{n}=222, \% 49.78)$, tübülovillöz adenomlar ( $\mathrm{n}=29, \% 6.50)$, villöz adenomlar ( $\mathrm{n}=3$, $\% 0.67)$, serrated polipler/adenomlar ( $n=14, \% 3.14)$ intramukozal adeno $\mathrm{Ca}(\mathrm{n}=1, \% 0.22)$, nöroendokrin tümördür $(\mathrm{n}=1$, $\% 0.22$ ). Non neoplastik poliplerimize (\%39.5) göz atacak olursak, bu grupta en sik görülen lezyon hiperplastik poliplerdir ( $\mathrm{n}=131, \% 29.37)$, ardından non spesifik/ödematöz mukoza ( $\mathrm{n}=19, \% 4.26)$, inflamatuvar polipler $(\mathrm{n}=18, \% 4.03$ ) olarak sıralanmaktadır. Ülkemizde yapılan yukarıda da adı geçen çalışmalarda sırasıyla $\% 75.7, \% 49.73, \% 74.4, \% 76.25$ oranları ile kolonda tespit edilen poliplerin histolojik tipleri açısından en büyük grubunu neoplastik polip grubunun oluşturduğu görülmüştür $(2,17,25,26)$. Korkmaz ve ark. ve Eminler ve ark.'nın çalışmasında neoplastik grup içinde en slk $\% 67.2$ ve $\% 68.0$ ile tübüler adenomlar, \%6.6 ve $\% 7.2$ ile tübülovillöz adenomlar, $\% 0.8$ ve $\% 0.5$ ile villöz adenomların oluşturduğu bildirilmişken, 2 adet (\%0.5) ve 7 adet de (\%0.8) adeno Ca saptanmıştır. Aynı çalışmalarda non neoplastik polip grubundan $\% 12.5$ ve $\% 4.3$ ile hiperplastik polipler, \%6.6 ve $\% 12.0$ oranı ile mukozal doku saptanmıștır $(2,17)$.

Bizim çalışmamız ve neredeyse tüm klinik çalışmalar da histolojik olarak değerlendirildiğinde, tübüler adenom kolonun tüm lokasyonlarında en sık saptanan polip tipi olarak bildirilmiştir. Korkmaz ve ark.ve Eminler ve ark. çalışmalarında sirasiyla poliplerden \%15.55 ve \%14.22'sinde LGD, \%5.68 ve \%5.0'inde HGD varlığı saptanmışken, bizim çalışmamızda displazi sıklı̆ımız \%56.51 (LGD: \%55.16, HGD: \%1.35) olarak saptanmış olup ülkemiz çalışmalarından oldukça yüksek, ABD ve Avrupa çalışmalarına benzer ve bir miktar yüksek orandadır $(2,17)$.

Özetleyecek olursak kolorektal polip prevalansımız ülkemiz çalışmalarına benzer, batı literatüründen düşük sıklıktadır. Kolorektal polip saptadığımız hastalarımızın yaş ortalaması ve cinsiyet oranı, literatüre benzer şekilde ileri yaş ve erkek cinsiyet baskındır. Literatürde en sık polip lokalizasyonu rektum iken bizim çalışmamızda sigmoid kolon olarak saptanmıştır. Polip boyutu göz önüne alınacak olursa çalışmamızda $1 \mathrm{~cm}$ altı polip sıklığımız literatüre göre daha yüksek sıklıktadır. Polip histopatolojisinde en sık gördüğümüz lezyon adenomlar olup, en sık adenom tipi de tübüler adenom olarak 
saptanmış olup literatürle uyumludur. Neoplastik polip oranımız literatürdeki benzer çalışmalara göre daha az sıklıkta iken özellikle LGD olmak üzere displazi sıklığımız literatürdeki benzer çalışmalardan daha yüksek oranlardadır.

Çalışmamızdan da anlaşılacağı üzere kolorektal polip prevalansı yüksektir, ancak ülkemizde daha fazla vaka içeren, çok merkezli, geniş çaplı polip prevalans çalışmalarına da ihtiyaç vardır. Poliplerin azımsanmayacak kısmı neoplastik ve

\section{KAYNAKLAR}

1. Itzkowitz SH, Potack J. Colonic Polyps and Polyposis Syndromes. In: Sleisenger and Fordtran's Gastrointestinal and Liver Disease. (Eds.) Sleisenger MH, Fordtran JS. 8th ed. Philedeplhia, Saunders. P.2713-36.

2. Korkmaz H, Kendir IC, Akkaya Ö. Evaluation of size, localization and histopathologic structures of colonic polyps (Kolon poliplerinin boyut, lokalizasyon ve histopatolojik yapılarının değerlendirilmesi). Endoscopy 2016;24:13-7.

3. Arnold M, Sierra MS, Laversanne M, et al. Global patterns and trends in colorectal cancer incidence and mortality. Gut 2017;66:683-91.

4. Ferlay J, Shin HR, Bray F, et al. Estimates of worldwide burden of cancer in 2008: GLOBOCAN 2008. Int J Cancer 2010;127:2893-917.

5. Konishi F, Morson BC. Pathology of colorectal adenomas: A colonoscopic survey. J Clin Pathol 1982;35:830-41

6. Boland CR, Itzkowitz SH, Kim YS. Colonic polyps and gastrointestinal polyposis syndromes. In: Gastrointestinal Disease, (Eds) Sleisenger MH, Fordran JSS. Philadelphia, WB Saunders Company 1989;2:1483-518.

7. Mangas-Sanjuan C, Jover R, Cubiella J, et al; Grupo de Cribado del Cáncer Color-rectal de la Sociedad Española de Epidemiología. Endoscopic surveillance after colonic polyps and colorectal cancer resec $\neg$ tion. 2018 update. Gastroenterol Hepatol 2019;42:188-201.

8. Belviranlı M, Yıldırım MA. Serrated Polyps. Turkiye Klinikleri J Gen Surg-Special Topics 2017;10:288-91.

9. Brenner H, Hoffmeister M, Stegmaier C, et al. Risk of progression of advanced adenomas to colorectal cancer by age and sex: estimates based on 840.149 screening colonoscopies. Gut 2007;56:1585-9.

10. Atkin WS, Saunders BP, British Society for Gastroenterology; Association of Coloproctology for Great Britain and Ireland. Surveillance guidelines after removal of colorectal adenomatous polyps. Gut 2002;51(Supp 5):V6-9.

11. Atkin WS, Morson BC, Cuzick J. Long-term risk of colorectal cancer after excision of rectosigmoid adenomas. N Engl J Med 1992;326:658-62.

12. Williams AR, Balasoorriya BAW, Day DW. Polyp and cancer of the large bovel: A necropsy study in Liverpool. Gut 1982;23:835-42.

13. Vatn MH, Staisberg $H$. The prevalence of polyps of the large intestine in Osio: An autopsy study. Cancer 1982;49:819-25.

14. Nam SY, Kim BC, Han KS, et al. Abdominal visceral adipose tissue predicts risk of colorectal adenoma in both sexes. Clin Gastroenterol Hepatol 2010;8:443-50.

15. Nguyen SP, Bent S, Chen YH, Terdiman JP. Gender as a risk factor for advanced neoplasia and colorectal cancer: a systematic review and meta-analysis. Clin Gastroenterol Hepatol 2009;7:676-81.

16. Altınparmak E, Sezgin O, Parlak E, Altıntaş E. Colorectal polyps 'The Yüksek thtisas experience'. Turk J Gastroenterol 2001;12:49-52.

17. Eminler AT, Sakallı M, Irak K, et al. Colonoscopic polypectomy results of our gastroenterology unit (Gastroenteroloji ünitemizdeki kolonoskopik polipektomi sonuçlarımız). Akademik Gastroenteroloji Dergisi 2011;10:112-5

18. Schatzkin A, Lanza E, Corle D et al. Lack of effect of a low-fat, high fiber diet on the recurrence of colorectal adenomas. Polyp Prevention Trial Study Group. New Eng J Med 2000;342:1149-55. displastik özellikler taşımaktadır. Aynı zamanda ülkemizde ve dünyada en slk görülen kanserlerden olan KRK gelişimini azaltmak ve önleyebilmek için daha fazla kolonoskopik tarama yapılması ve görülen poliplerin usulüne uygun olarak çıkarılması ve deneyimli patologlarca histolojik özelliklerinin ortaya konması hayati öneme haizdir.

\section{"Tüm yazarlar herhangi bir çıkar çatışması olmadığını be- yan ederler."}

19. Jass JR. Subsite distribution and incidence of colorectal cancer in New Zealand, 1974-1983. Dis Colon Rectum 1991;34:56-9.

20. American Cancer Society Guideline for Colorectal Cancer Screening, Last Medical Review: February 21, 2018 Last Revised: May 30, 2018.

21. Lieberman DA, Rex DK, Winawer SJ, at al. Guidelines for Colonoscopy Surveillance After Screening and Polypectomy: A Consensus Update by the US Multi-Society Task Force on Colorectal Cancer, Gastroenterology 2012;143:844-57.

22. The American Cancer Society medical and editorial content team, Key Statistics for Colorectal Cancer, Last Medical Review: February 21, 2018, Last Revised: January 8, 2020.

23. Winawer SJ, Zauber AG, Fletcher RH, et al; US Multi-Society Task Force on Colorectal Cancer; American Cancer Society. Guidelines for colonoscopy surveillance after polypectomy: a consensus update by the US Multi-Society Task Force on Colorectal Cancer and the American Cancer Society. Gastroenterology 2006;130:1872-85.

24. Dolek Y, Karabulur YY, Topal F, et al. Gastrointestinal poliplerin boyut, lokalizasyon ve histopatolojik tipleriyle değerlendirilmesi. Endoskopi 2013;21:31-3.

25. Şahintürk Y, Çekin AH. Colon polyps localization, histology, and size-five years colonoscopic research. Endoscopy 2018;26:57-60.

26. Solakoğlu T, Atalay R, Köseoğlu H, et al. Analysis of 2222 colorectal polyps in 896 patients: A tertiary referreal hospital study. Turk J Gastroenterol 2014;25:175-9.

27. Giovannucci E. Epidemiologic studies of folate and colorectal neoplasia: a review. J Nutr 2002;132(8 Suppl):2350S-5S.

28. Markowitz AJ, Winawer SJ. Management of colorectal polyps. CA Cancer J Clin 1997; 47: 93-112.

29. Rex DK. Colonoscopy: A review of its yield for cancers and adenomas by indication. Am J Gastroenterol 1995;90:353-65.

30. Hoff G, Foerster A, Vatn MH, et al. Epidemiology of polyps in the rectum and colon: recovery and evaluation of unresected polyps 2 years after detection. Scand J Gastroenterol 1986;21:853-62.

31. Pooler BD, Kim DH, Weiss JM, et al. Colorectal polyps missed with optical colonoscopy despite previous detection and localization with CT colonography. Radiology 2016;278:422-9.

32. Gupta N, Bansal A, Rao D, et al. Prevalence of advanced histological features in diminutive and small colon polyps. Presented at Digestive Disease Week, May 5-8, 2011, Chicago, Illinois. Gastrointest Endosc 2011;73:AB159-60

33. Heitman SJ, Ronksley PE, Hilsden RJ, et al. Prevalence of adenomas and colorectal cancer in average risk individuals: a systematic review and meta-analysis. Clin Gastroenterol Hepatol 2009;7:1272-8.

34. Butterly LF, Chase MP, Pohl H, Fiarman GS. Prevalence of clinically important histology in small adenomas. Clin Gastroenterol Hepatol 2006;4:343-8.

35. Suna N, Köksal AŞ, Yıldız H, et al. Prevalance of advanced hisologic fetures in diminutive colon polyps. Acta Gastroenterol Belg 2015;78:28791. 